\title{
Wilson Sirozlu Hastanın Bakımında Levine Koruma Modelinin Kullanımı
}

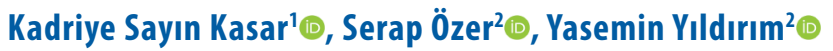

\begin{abstract}
'Aksaray Üniversitesi, Sağlık Bilimleri Fakültesi, Iç Hastalıkları Hemşireliği Anabilim Dalı, Aksaray, Türkiye 'Ege Üniversitesi, Hemşirelik Fakültesi, Iç Hastalıkları Hemşireliği Anabilim Dalı, İzmir, Türkiye
\end{abstract}

Kadriye Sayın Kasar, Arş. Gör. Dr. Serap Özer, Doç. Dr. Yasemin Yıldırım, Prof. Dr.

\section{Illetişim:}

Arş. Gör. Dr. Kadriye Sayın Kasar

Aksaray Üniversitesi, Sağlık Bilimleri Fakültesi, İç Hastalıkları Hemşireliği Anabilim Dalı, Aksaray, Türkiye

Tel: +903822882790

E-Posta:kadriye_syn_321@hotmail.com
Gönderilme Tarihi : 06 Ekim 2017

Revizyon Tarihi : 04 Aralık 2017

Kabul Tarihi : 06 Aralık 2017

\section{ÖZET}

Siroz; sağlığı ciddi bir şekilde tehdit eden, üretkenlik kaybına neden olan, sık izlem gerektiren ve maliyeti yüksek önemli kronik bir sağlık sorunudur. Siroz gibi kronik sağlık sorunlarının bakımında modellerin kullanımı analitik düşünme becerisini, amaç belirleme ve geliştirme yeteneğini kazanmada hemşireye rehberlik etmektedir. Bu modellerden birisi olan Levine Koruma Modeli'nin amacl; uyumu desteklemek için koruma ilkelerini kullanarak bireyin bütünlüğünü sağlamaktır. Hemşire enerjinin, yapının, bireysel ve sosyal bütünlüğün korunması yoluyla modeldeki hedefleri gerçekleştirmektedir.

Bu makalede; Levine Koruma Modeli açıklanmış ve Wilson Sirozu olan 29 yaşındaki bir kadın hastanın bakımında model kullanımına yönelik bir örnek oluşturulmuştur.

Anahtar sözcükler: Wilson Sirozu, Levine Koruma Modeli, Hemşirelik

THE USE OF LEVINE'S CONSERVATION MODEL IN THE CARE OF PATIENTS WITH WILSON'S CIRRHOSIS

\section{ABSTRACT}

Cirrhosis; is a costly and chronic health problem that seriously threatens health, causes loss of productivity, requires frequent follow-up. The use of models for the care of chronic health problems such as cirrhosis guides the nurses to care about acquiring analytical thinking skills, ability to identify and develop goals. One of these models is Levine's Conservation Model and the aim of the model is to ensure the integrity of the individual using conservation principles to promote harmony/compliance. A nurse can achieve the objectives of the model through the conservation of energy, structure, individual and social integrity.

In this article; Levine's Conservation Model was explained. It is an example of the use of the model in the care of a 29-year-old female patient with Wilson's disease.

Keywords: Wilson's Cirrhosis, Levine's Conservation Model, Nursing

iddi kronik bir hastalık olan siroz; önemli komplikasyonlarla seyreden, yakın ve sık izlem gerektiren, maliyeti yüksek, üretken yaşamın kaybedilmesi nedenleriyle yaşam kalitesini azaltabilen önemli bir sağlık sorunudur $(1,2,3)$. Siroz viral hepatit gibi enfeksiyöz nedenlere ya da alkol ve genetik faktörler gibi enfeksiyon dışı nedenlere bağlı gelişebilmektedir $(4,5)$. Enfeksiyon dışı nedenlerden olan Wilson Hastalığı (WH), bakır metabolizmasındaki bozukluğa bağlı olarak karaciğer ve beyinde dejeneratif değişikliklere yol açan, 13. kromozomun uzun kolunda değişik mutasyonlarla karakterize, otozomal resesif geçiş gösteren nadir görülen bir hastalıktır $(6,7)$. 
Illk defa 1912 yılında Samuel Alexander Kinner Wilson tarafından tanımlanan WH'nda, bakırın seruplazmin ile birleşip taşınması ve aşııı bakırın safra ile atılması süreci bozulmaktadır $(7,8)$. Serumda düzeyi yükselen bakır karaciğer, beyin ve böbreklerde birikerek hastalığa neden olmaktadır $(6,7)$. Başlangıçtaki klinik belirtiler hepatik, nörolojik, hematolojik, psikiyatrik ve renal belirtiler şeklinde olmaktadır. Hastalığın seyri yıllar içerisinde asemptomatik tablodan karaciğer sirozuna kadar ilerleyebilmektedir (8). Klinik tablo değişken olmakla birlikte karaciğer hastalığı ve siroz, nöropsikiyatrik bozukluklar, korneada KayserFleischer halkası ve sıklıkla akut karaciğer yetmezliği ile ilişkili akut hemolitik anemi WH'nın önemli bulguları arasında yer almaktadır $(9,10)$. Akut karaciğer yetersizliği gelişen fulminan WH olgularında plazma değişimi ve şelasyon tedavileri geçici düzelme sağlayabilse de küratif tedavi karaciğer naklidir (10). Ayrıca gen tedavisi de günümüzde uygulanmaya başlanan seçenekler arasındadır (8).

Hastalığın yarattığı değişiklikler ve komplikasyonlar nedeniyle günlük yaşam, sosyal yaşam, iş yaşamı ve cinsel yaşam olumsuz etkilenmektedir $(3,11,12)$. Hastalarda impotans, infertilite, jinekomasti ve koltuk altı kıllarının azalması gibi endokrin değişiklikler, anoreksiya ve zayıflık, kas kaybı, malnutrisyon ve periferik nöromiyopati gibi fizyopatolojik değişiklikler, assit, ödem gibi bulgular, kanama ve ensefalopati gibi komplikasyonlar görülebilmektedir $(1,3)$. Ayrıca hastalık yorgunluk, uyku problemleri, aktivitede azalma ve hareketsizliğe neden olabilmektedir. Tüm bu olumsuz etkiler ve sonuçlar nedeniyle bakım yönetimi sürecinde; sirozlu hasta ve ailesinin, tedaviye uyum, komplikasyon kontrolü ve koruyucu uygulamalar açısından desteklenmesi, psikososyal yardımın sağlanması ve sağlık eğitimi ile güçlendirme yaklaşımlarının uygulanması gerekmektedir (13).

Hemşirelik kuramlarına dayandırılmış bakım modelleri; bakım yönetimi sürecinin sürdürülmesine rehberlik ederken hemşirenin analitik düşünme becerisi geliştirmesine, amaç belirleme ve geliştirme yeteneği kazanmasına katkı sağlamaktadır $(14,15,16)$. Bakım modellerinden Levine Koruma Modeli (KM); uyumu destekleyerek koruma ilkelerini kullanmayı ve bireyin bütünlüğünü sağlamayı amaçlamaktadır. Modelde hemşire enerjinin, yapının, bireysel ve sosyal bütünlüğün korunması yoluyla hedeflerine ulaşmaktadır. Aynı zamanda tepkiler üzerine odaklanmaktadır $(17,18)$.

Bu doğrultuda makalemizde; KM'i temel alınarak WH tanısıyla bir Eğitim ve Araştırma Hastanesinin Gastroenteroloji
Kliniğine yatırılan 29 yaşındaki kadın hastanın enerji, yapısal, bireysel ve sosyal bütünlüğü değerlendirilmiş, bakım süreci açıklanmaya çalışılmıştır. Dolayısıyla; modelin açıklanıp sirozlu hastanın bakımına uyarlanması amaçlanmıştır. Ayrıca modelin bakım yönetimi süreci ile kolaylıkla bütünleştirilebileceği ve uygulamalarda kullanılabileceği vurgulanmıştır.

\section{Koruma modeli}

Myra Levine tarafından geliştirilen kuram, bireysel yaşam kalitesinin iyileştirilmesini hedeflemektedir. Levine, hemşireliğin temelinin insan etkileşimi olduğuna inanmakta ve bu doğrultuda hareket etmektedir (17). Koruma modelinin üzerinde durduğu temel kuram hemşirelik girişimlerindeki koruma aktiviteleridir (18).

Modelin ana kavramı olan bireyin korunması sağlık sorunlarına uyum sağlaması anlamına gelmektedir (19). Model, uyum, bütünlük ve koruma temel kavramlarını içermektedir. Uyum; bir değişim sürecidir ve koruma uyumun bir sonucudur. Uyum "birey tarafından çevresel kaynakların kendi yararına, tedbirli, ekonomik ve kontrollü kullanımı" yoluyla gerçekleştirilmektedir. Çevreyle etkileşim veya sürekli uyum bütünlüğün izin verdiği ölçüde sağlanmaktadır. Koruma, uyumun bir ürünüdür. Yaşam sistemleri ve bireyin bütünlügünün bir arada tutulması olarak tanımlanmakta ve bireyin biyolojik durumu ile arz ve talep arasındaki dengeyi sağlamaktadır.

Levine modelinde diğer kuramcılar gibi hemşirelik ve korunma kavramlarını dört alt boyutta açıklamıştır.

\section{Hemşirelik kavramları}

Birey; bütüncül bir varlık olarak sürekli bütünlüğünü korumak için çaba göstermektedir.

Sağlık; Levine "iyilik" kavramı yerine "sağlık" kavramının kullanılmasını uygun görmektedir.

Hastalık; Levine'e göre; "hastalık döneminde, bireyin sağığını korumaya ve yaşamını devam ettirmeye çalışması" olarak belirtilmektedir.

Çevre; bireyin bütünlüğünü tamamlayan bir öğe olarak kabul edilmektedir. Çevre fizyolojik ve patofizyolojik unsurların yanı sıra bedensel işlevlerin etkileşiminden oluşan iç çevre ve algısal (kişinin duyularla algıladığı çevre, örn; dokunuş), çevresel (kişiyi kuşatan ancak farkında olmadığı çevre, örn; hava kirliliği) ve kavramsal (kişinin dil, düşünce, 
değer ve inançlarını deneyimlediği çevre) olarak üç düzeyde sınıflandırılan dış çevreden oluşmaktadır (19).

Koruma Modeli'nin tek odağı bireyin bütünlüğünü korumak ve çevredeki değişikliklere uyumunu sağlamaktır. Model bireylerin, uyuma karşı göstermiş olduğu tepkiler üzerinde durmakta, hemşirenin dikkati ile iç ve dış çevrede olan iletişim sorunlarını fark etmesini kapsamaktadır. Ayrıca KM'de hemşirenin sorumluluğu, hastanın enerjisini yüksek tutmasını, bireysel ve sosyal anlamda kendini bulunduğu ortama dahil etmesini sağlamaktır. Koruma kavramı dört boyutu içermektedir. Bu boyutlar (19);

1. Enerjinin korunması: Bu boyutta amaç; enerji çıktısının dengelenmesini ve enerji girdisinin gereğinden fazla olması durumunda (yeterli dinlenme, beslenme ve egzersiz gibi aktivitelerde) uzak durulmasını sağlamaktır. Enerjinin korunması, enerjinin dikkatli kullanılmasını ifade etmektedir. Birey enerjisini korumasına rağmen, yaşamsal enerjiyi güçlendiren aktiviteler, biyolojik ve kimyasal değişimler enerjiyi tüketmektedir. Levine enerjinin doğrudan gözlenemediğini ancak tahmin edilebilir, uygulanabilir ve sınıflandırılabilir olduğunu belirtmektedir. Hastalık durumunda enerjinin korunması en temel konudur (Örn; yeterli dinlenmeyi sağlama, yeterli beslenmeyi sürdürme) $(19,20,21,22)$.

2. Yapısal bütünlüğün korunması: Vücut yapılarının yenilenmesi ya da sürekliliğinin sağlanması, yani fiziksel bozulmaların önlenmesi ve sağlığın devamı yapısal bütünlük kapsamına girmektedir. Birey aktiviteleri seçmekte özgürdür. Sağlık (tümü ile ele alındığında) bağışıklık sisteminin etkinliğinin bir sonucudur. Çevrenin tehdit edici unsurlarına karşı bireysel korunma en az çabayla tamamlanmaktadır. Eklem hareket açıklığı egzersizlerinde bireye yardım etmek ve bireysel hijyeni sürdürmek bu kapsamda verilebilecek örnekler arasında yer almaktadır $(19,20,21,22)$.

3. Bireysel bütünlüğün korunması: Bireyin duygularını yenilemesi, duygularının sürekliliğini sağlaması ve kendine verdiği değer bu bütünlüğün kapsamındadır. Bireyselliğin kalıcı, her bireyin kendine özgü ve tek olduğu vurgulanmaktadır. Bireyin saygı, farkındalık, benlik ve kendi geleceğini belirlemesi gibi gereksinimlerini tanıması ve koruması bu boyuta örnek olarak verilebilir.

4. Sosyal bütünlüğün korunması: Aile, toplum, kültür, kalıtım, dini inançlar, sosyoekonomik farklııklar, eğitimsel altyapı, mesleki tercihler gibi sosyal bir varlık olan bireyin kimliğini oluşturan faktörler bu boyutta değerlendirilmektedir. Bireysellik çevre tarafından oluşturulmakta ve yine onun içinde değişime uğramaktadır. Bireyi yaşadığı çevreden soyutlayarak tanımlamak imkânsızdır. Hastanede yatan hastayı diğer hastalar ile sosyal etkileşime teşvik etmek, aileye destek ve yardım sağlamak sosyal bütünlüğün korunması kapsamında örnek olarak verilebilir.

Levine'in kuramı ve hemşirelik sürecinin birçok unsuru paraleldir. Levine'e göre; hemşire hastayı gözlemlemekte, uygun girişimlere karar vermekte, bu girişimleri uygulamakta ve uygulamayı değerlendirmektedir (Tablo1) $(17,19,20,21,22)$.

\section{Modelin wilson sirozlu hastanın bakım yönetimi sürecinde kullanılması}

Bu makaledeki vaka ÜD; 29 yaşında, bekâr, kadın, üniversite mezunu ve anaokulu öğretmeni (5 yı öncesi) olmakla birlikte şu anda aktif olarak çalışmamaktadır. Sosyal güvencesi olan hasta, ailesi ile birlikte yaşamaktadır. Bilinen WH nedeniyle izlenen ÜD'ye altı yıl önce kadavradan karaciğer nakli yapılmıştır. Son altı aydır ikterik görünümün artması ve son günlerde başlayan diyare nedeniyle dış nakil merkezine başvurmuştur. Hastaya perkütan transhepatik kolanjiyografi (PTK) yapılmış ancak bilirubin değerlerinde düşme olmaması nedeni ile yakın izlem amaçlı hastaneye yatırılmıştır. Yardımsız yürüyemeyen, dişlerinin kilitlenmesine bağlı konuşamayan ancak konuşulanları anlayan hasta kendini halsiz ve yorgun hissettiğini, yemek yemek istemediğini bildirmektedir. Nakil sonrası üç-dört yıldır genel durumunun eskiye oranla daha iyi olduğunu ifade edilmektedir. Özgeçmiş ve soy geçmiş değerlendirildiğinde; herhangi bir özellik olmadığı görülmektedir.

Vakanın verileri kendisinin onamı alındıktan ve süreç açıklandıktan sonra modelin dört ilkesi rehber alınarak toplanmıştır.

Hastanın enerji kaynakları ile ilgili veriler; ÜD'nin son bir ayda sekiz kilo kaybettiği belirlenmiştir (beden kitle indeksi: $19.2 \mathrm{~kg} / \mathrm{m}^{2}$ ). Ailesinin ifadelerine göre iştahı oldukça az olan hasta dişlerindeki kilitlenmeye bağlı olarak özellikle püre, sıvı kıvamda besinler alabilmektedir. Salya akması ve yemek sonrası oluşan bulantı ve şişkinlik yakınmaları bulunmaktadır. Günlük uyku süresini ve kalitesini yetersiz olarak değerlendiren hastanın, hastane ortamı ve ağrılarına bağlı olarak gece sık uyandığını ve günlük ancak beş-altı saat kadar uyuyabildiğini ifade edilmektedir. Ayrıca yorgunluk ve kontraktür nedeniyle günlük gereksinimlerini karşılayamayan hastanın bakıma gereksinimi 


Süreç
Veri Toplama
Sürecin bu aşamasında; koruma ilkeleri dikkate alınarak sorun oluşturan
olaylar görüşülür ve ortamdaki zorluklar gözlem yapılarak çözümlenir. Gözlem
aşamasında hemşireler ilk olarak hasta bakımında kendilerine düşen rolü
belirlemelidir.

1. Enerjinin korunması

2. Yapısal bütünlük

3. Bireysel bütünlük

4. Sosyal bütünlük

\section{Karar-Trofikognozis}

Hemşirelik tanısının belirlendiği bu aşamada sorun oluşturan gerçekler anlamlandırilır. Levine trofikognozis'i hemşirelik tanısının alternatifi olarak sunmaktadır. Bu kavram; hemşirelik tanıları tıp sözlüğünde "tanı bilgisi" olarak ifade edilmektedir. Levine hemşirelik tanısı kavramının trofikognozis ile eş anlamlı kullanımları olan araştırma, yargılama, sorunlar, gereksinimler veya değerlendirme kavramları şeklinde kullanılmasının yanlış olduğunu belirtmiştir. Bunun nedeni de hemşirelik tanısı kavramının yasal bir yorumunun olması ve onunla aynı anlama gelen diğer kavramların sadece algısal olarak tanı kavramı ile aynı anlamda kullanılmasıdır.

\section{Hipotezler}

Doğrudan bütünlüğü korumayı ve uyumu desteklemeyi hedefleyen hemşirelik girişimleri sürecin hipotezler aşamasını oluşturmaktadır.

\section{Girişimler \\ Levine, hemşirenin becerisinin bilgisine dayandığını vurgulamakta ve bakım planında hastanın katıımını göz önünde bulundurmaktadır. Modele göre; hasta birey, kendi semptomlarının farkına varmalı, semptomlarla baş edebilmeli ve semptomların tedavisinde uygun yöntemi seçebilmelidir. Koruma tüm hemşirelik girişimleri için temel bir rehber olup, bakıma karar vermede bilimsel yaklaşım olarak değerlendirilmektedir. Levine hasta olan bireyin geçici olarak hemşireye bağımlı olduğu görüşünü benimsemektedir. Hemşirenin amacl; bağımlılı̆ı mümkün olduğu kadar çabuk sona erdirmek ve hastanın uyumunu yeniden sağlamaktır. Yani sağlık bakımına bağımlı olan birey hastadır. Hemşire sorun ne ise ona göre hizmet vermektedir. Bakım planı uygulamaya konulduğunda hastanın yanıtı gözlenmektedir. Hemşire, uygulama aşaması boyunca hastaya bakım vermekten sorumludur.}

\section{Değerlendirme}

Sürecin son aşaması olan değerlendirme aşamasında girişimlere organizmanın verdiği yanit gözlemlenir. Hipotezlerin desteklendiği veya desteklenmediği değerlendirilmektedir. Değerlendirme hem destekleyici hem de terapötik sonuçları kapsamalıdır. Eğer hipotez desteklenmiyorsa, plan revize edilmekte ve yeni hipotezler önerilmektedir.

\section{Karar Verme}

Hemşire, hastalık nedeniyle gelişen organizma yanıtlarını gözlemler, tıbbi raporları okur, tanı çalışmalarının sonuçlarını değerlendirir ve gereksinimleri hakkında yardımcı olmak için hastalarla iletişime geçer. Hemşire iç ve dış ortamlardaki hasta sorunlarını değerlendirir. Koruma ilkelerini dikkate alarak elde ettiği girişimleri, uygulamadaki güçlükleri değerlendirir.

1. Enerjinin arz ve talep dengesi

2. Vücudun savunma sistemi

3. Bireyin öz-değeri ve birey olma duygusu

4. Bireyin sosyal sisteme katılma yeteneği

Bu veriler sorun oluşturan gerçeklerdir.

Sorun oluşturan durumlar hastanın içinde bulunduğu durumu anlamlandıracağı şekilde düzenlenmişstir. Hastanın gereksinimleri ile ilgili yargular trofikognosis olarak adlandırılır.
Hemşireler kendi değerlendirmesine dayanarak belirlediği sorun hakkında hastadan doğrulama bekler. Hemşire sorun ve çözüm hakkında hipotezler ileri sürer - bu da bakım planıdır.

Hemşireler bakımı yönetmek için hipotezleri kullanır.

Aslında, hemşire hipotezleri önerir. Girişimler enerjinin, yapısal bütünlük, bireysel bütünlük ve sosyal bütünlüğün korunması şeklinde koruma ilkeleri doğrultusunda tasarlanmıştır. Yaklaşımın amacı bütünlük sağlamak ve uyumu desteklemektir. bulunmaktadır. Yaklaşık iki aydır konstipasyonu olan ÜD'nin son beş gündür defekasyonu yoktur. Barsak sesleri normal olup günlük sıvı alımı yetersizdir (1200ml).

\section{"Enerjinin korunması" boyutuna yönelik hemşirelik tanılarl;}

- Dişlerde kilitlenmeye bağlı Yutmada bozulma

- Uyku süresi ve kalitesinde azalma, beden gereksiniminden az beslenme ve hastalık semptomlarına bağlı Yorgunluk (8 puan)

- Yutma güçlüğü, iştahsızlık, dişlerde kilitlenme ve salya akmasına bağlı Beden gereksiniminden az beslenme
Hipotezleri destekleyen veya desteklemeyen organizma yanitlarını sonucu değerlendirilir. Bakım sonuçları terapötik ya da destekleyici olabilir: terapötik sonuçlar bireyin iyilik duygusunu geliştirirken, destekleyici sonuçlar hastalığın seyri artık bireyi etkilemediğinde konforu sağlar. Hipotezler desteklenmiyorsa, plan revize edilir ve yeni hipotezler önerilir.
- Yetersiz besin ve sıvı alımı, hareketsizliğe bağlı Konstipasyon

- Ağrı, hastane ortamında bulunmaya bağlı Uyku örüntüsünde bozulma

Yapı bütünlüğü ile ilişkili veriler; Genel olarak bilişsel durumu iyi olan hastanın anlama ve algılaması açıktır, ancak dişlerin kilitlenmesine bağlı konuşma güçlüğü bulunmaktadır. Hasta yardımsız yürüyememekte, yardımcı araç kullanmaktadır (tekerlekli sandalye ya da yakınlarından çift taraflı destek). Hastanın üst ve alt ekstremitelerinde kontraktür oluşmuş ve tüm vücutta yaygın kaşıntısı mevcuttur. 
Tükürük salgısında artışa bağlı salya akışı bulunmaktadır. Hastanın hepatomegali ve splenomegalisi mevcuttur. Vizüel Analog Skala (VAS) ile yapılan ağrı değerlendirmesinde ağrı şiddeti puanını üç, yorgunluk şiddeti puanını da sekiz olarak belirtmektedir. Kullandığı ilaçlar; maxipen (meronem) 1 gr. (3x1), zinco $50 \mathrm{mg}$. tablet (1x1), hepa-merz granül (3x2), metalcaptase $300 \mathrm{mg}(2 \times 1)$ ve duphalac süspansiyon 670 mg.(3x1)'dur. Laboratuvar bulgularl; $\mathrm{Hb}: 11.4$ mg/dl; Htc: \%36; Eritrosit: 3.75/ $\mathrm{mm}^{3}$; Lökosit: $2.81 / \mathrm{mm}^{3}$; CRP: $9.4 \mathrm{mg} / \mathrm{l}$; Sedimantasyon: $13 \mathrm{~mm} / \mathrm{sa}$; APTT: 65 sn, PTT: 75 sn, INR: 3.2, AST: 37 U/l; ALT: 23 U/l; Alkalenfosfataz: 104 U/l, Total bilirubin: $25 \mathrm{mg} / \mathrm{dl}$, Direkt bilirubin $22 \mathrm{mg} / \mathrm{dl}$ 'dir.

\section{"Yapısal bütünlügün korunması" boyutuna yönelik hemşirelik tanıları;}

- Hepatomegali ve hastalık sürecine bağlı Ağrı

- Deride bilirubin ve safra tuzlarının birikmesine bağlı rahatta bozulma Kaşıntı

- Kan koagülasyonu sentezinin azalmasına bağlı Kanama riski

- Kontraktür olması ve kaşıntıya bağlı Deri bütünlüğünde bozulma riski

- Hepatomegali ve splenomegali nedeniyle aşırı aktiviteye sekonder olarak gelişen lökopeniye bağlı Enfeksiyon riski

Bireysel bütünlük ile ilişkili veriler; ÜD, uzun süredir hastanede bulunması ve tedavi süreci nedeniyle stres ve duygusal olarak endişe yaşamaktadır. Bilişsel algılama yeteneği açık olan hasta artık eve gitmek istediğini ve hastanede olmaktan dolayı sıkıldığını ifade etmektedir. Hasta, üniversite mezunu olup anaokulu öğretmenidir. Hastalığı ve uzun süredir devam eden tedavi süreci nedeniyle öğretmenlik yapamamaktadır. Bu nedenle ciddi üzüntü ve keder yaşamaktadır. Ayrıca babasını özlediğini (babası Afyon'da) ve biran önce eve gitmek istediğini belirtmektedir.

\section{"Bireysel bütünlüğün korunması" boyutuna yönelik hemşirelik tanıları;}

- Görünümdeki değişikliklere bağlı Benlik kavramında rahatsızlık

- Tedavi sürecinin belirsizliği ve uzun süredir hastanede bulunmaya bağlı Anksiyete

Sosyal bütünlük ile ilişkili veriler; Uzun süredir bu hastalığa bağlı olarak sosyal yaşamı kesintiye uğrayan ÜD, evinden ve arkadaşlarından uzak kalmaktadır. Annesi ve ablası sürekli hastanede yanında bulunmaktadır. Hastanede bulunduğu süre içerisinde sağlık ekibi ve diğer hastalarla iletişim ve çevresine uyumda herhangi bir sorun yaşamamaktadır.

\section{"Sosyal bütünlüğün korunması" boyutuna yönelik hem- şirelik tanıları;}

$\checkmark$ Hastalık ve uzun süredir hastanede bulunmaya bağlı olarak Rolleri yerine getirmede yetersizlik

Yukarıda belirtilen hemşirelik tanılarına yönelik girişimler Tablo 2'de verilmiştir $(23,24)$.

Uygulanan girişimler sonrası ÜD’nin yutma güçlüğü, iştahsızlık ve ağız kilitlenmesine bağlı beslenme sorunun devam ettiği gözlenmiştir. Ayrıca iştahsızlık durumunun daha da arttığı gözlemlenmiştir. Girişimler sonrası ÜD'nin yorgunluk düzeyi VAS ile değerlendirildiğinde " 6 ", ağrı düzeyi " 1 " olarak belirlenmiştir. Hastanın gün içinde uyumasının azaldığı görülmüştür. Hastanın girişimler sonrası izleminin ikinci gününde defekasyon çıkışı olmuş ancak sonraki günler konstipasyon sorunu devam etmiştir. Gece uyku süresi iki gün boyunca yedi-sekiz saat şeklinde olmuştur. Kaşıntı sorunu izlem süresince zaman zaman azalmasına karşın devam etmiştir. Anksiyete düzeyinde izlemin ilk günlerine göre azalma olmuştur. Benlik kavramındaki rahatsızlık ve rolleri yerine getirmedeki yetersizlik devam etmektedir. Hastada herhangi bir travma, deri bütünlüğünde bozulma ve enfeksiyon bulgusuna rastlanmamıştır.

\section{Sonuç}

Sağlıklı toplum için bireyin kendi sağlığını korumaya yönelik çabalarına önem verilmesi gerekir. Bireyin kendi sağlığını korumaya yönelik geliştirilen modellerden biri Levine Koruma Modeli'dir. Merkezi insan olan KM; uyumu destekleyerek koruma ilkelerini kullanmayı ve bireyin bütünlüğünü sağlamayı amaçlamaktadır. Levine, hemşireliği bilimsel bilgi ve beceri temelli mesleki bir uygulama olarak tanımlamaktadır. Bunun için yapılacak işlerden ilki ve en önemlisi bireyin kendi sağlığını korumasını ve sürdürebilmesini sağlayacak bilgilerle donatılmış olmasıdır. Bu nedenle siroz gibi kronik hastalığı olan hastaların ve bakımından sorumlu kişilerin eğitilmesi ve sonuçlarının değerlendirilmesi önemlidir.

Sonuç olarak; bu olgu sunumunda KM uygulanabilmiş ve olumlu hasta sonuçları elde edilmiştir. 
Tablo 2. Hemşirelik girişimleri

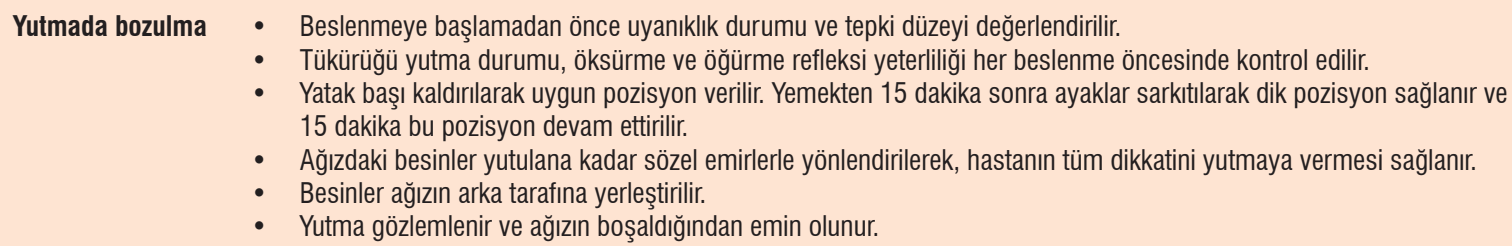

Yorgunluk • Yorgunluk ölçeği kullanılarak yorgunluk düzeyi değerlendirilir (VAS 8). Günlük yorgunluk düzeyi hasta ile birlikte analiz edilerek, en fazla enerjik olunan ya da bitkinlik yaşanan zamanlar ve yorgunluğu arttıran aktiviteler belirlenir.

- Yorgunluğun yaşam üzerindeki etkisi ve bununla ilişkili olarak neler hissettiğini açıklaması için hastaya olanak sağlanır.

- Yorgunluk hakkında bilgi verilir. Bunun için hastalık aktivitesi ile yorgunluk arasındaki ilişki açıklanır.

- Uygun aktivite/dinlenme programları geliștirilir.

- Enerjiyi korumaya katkı sağlayacak çevresel düzenlemeler konusunda açıklama yapııır.

- Dinlenmenin, emosyonel stres ve eklemlerdeki kontraktür sorunlarına sistematik olarak azaltıcı etkisi açıklanır.

Ağrı - Ağı lokalizasyonu, şiddeti ve yoğunluğu değerlendirilir (VAS 3).

- Ağrıyı arttıran ve azaltan faktörler belirlenerek, ağrı durumunda hastada görülen belirtiler gözlemlenir.

- Kas gerilimini azaltmak için ekstremitelere yavaş ve uygun teknikle masaj yapılır. Eklem sertliği ve kontraktür oluşumunu azaltmak için eklem hareket açıklığı egzersizleri yaptıııır.

- Aktiviteler ailenin de yardımıyla desteklenir.

- Alternatif ağrı giderme teknikleri (derin nefes alıp verme, oyalama, gevşeme, meditasyon) uygulanır ve öğretilir.

- Hekim istemine göre kullanılan analjeziklerin düzenli izlemi yapııır ve planlı faaliyetler analjezik etki oluşup ağrı kontrolü sağlandıktan sonra gerçekleştirilir.

- Ağrı durumunun paylaşılması sağlanır.

Beden gereksiniminden az beslenme
- Boy, kilo, 24 saatlik beslenme şekli, sıvı alma durumu ve diğer faktörler değerlendirilir.

- Diyetisyen ile işbirliği yapılarak günlük kalori ve uygun besin gereksinimi belirlenir ve bu konuda aileye de bilgi verilir.

- Yutma güçlüğü ve dişlerdeki kilitlenmeye bağı yeme süresi normalden daha uzun tutulur ve bu konuda hasta yakınları bilgilendirilir.

- Yemekten önce uygun bir ortam hazırlanır (odayı havalandırma vb.).

- Ağız hijyeni değerlendirilir ve sürekliliği sağlanır.

Konstipasyon • Hastanın günlük bağırsak alışkanlıkları değerlendirili.

- Yeterli beslenme ve hidrasyon sağlanır.

- Boşaltım için düzenli bir zaman belirlenip her gün aynı saatlerde boşaltım yapılması önerilir.

- Defekasyon gereksinimi doğduğunda ertelenmemesi gerektiği anlatılır.

- Hasta yatak içinde oturtularak vücudun bir sağ bir sol yapacak şekilde hareket etmesi sağlanır.

- Gerekli durumlarda doktor istemine uygun lavman yapilır.

- Genital bölge kontaminasyondan korunur.

- Diyetisyenle iş birliği yapılarak hastanın beslenmesi düzenlenir.

Kaşıntı • Hastanın cildi lezyon yara, kuruluk ve pullanma yönünden değerlendirilir.

- Tırnakların kısa ve düz kesilmesinin, temizliğine dikkat edilmesinin önemi öğretilir.

- Deri bütünlüğü bozulmuş bölgelerde enfeksiyon belirtileri izlenir.

- Serin bir çevre sağlanır.

- Doktor istemine göre cilde nemlendirici, besleyici ya da antihistaminik kremlerle masaj yapilır.

- Banyo yaparken sıcak su kullanmaktan kaçınıması, Iık su kullanılması ve banyo sonrasında vücudun yumuşak bir havlu ile ovuşturulmadan nazikçe kurulanması önerilir.

- Hastanın dar, yünlü ve sentetik kıyafetler giymekten kaçınması, özellikle yumuşak dokuma, ter emici, pamuklu kumaşlardan yapılmış bol kıyafetler giymesi önerilir.

- Hastanın dikkati başka yöne çekilerek kaşıntıya odaklanması azaltılabilir.

- Aromaterapi, akupuntur-akupresur gibi nonfarmakolojik yöntemler hakkında bilgilendirme yapıır.

Uyku örüntüsünde bozulma
- Uyku durumu değerlendirilir. Gece uykuyu bölen durumlar sorgulanır.

- Uykuyu etkileyebilecek yorgunluk, ağrı, gürültü gibi diğer durumlar hasta ailesi ile birlikte değerlendirilir.

- Rahatsız edici işlemler uyku dönemlerinin dışında ve en az sayıda olabilecek şekilde düzenlenir.

- Hastaya gün içinde ilgilenebileceği yatak içi aktiviteler önerilir.

- Gündüz uyumaları azalırsa gece daha rahat uyunabileceği ifade edilir.

- Gün içindeki şekerlemeler izlenir.

- Hastalık süreci anlatıır ve soru sorulmasına izin verilir. Hastaya kendini anlatması için ortam sağlanır ve etkili dinleme gerçekleştirilir.

- Hasta ile kısa, basit ve sakin konuşulur. Gerektiğinde yazıı iletişim sağlanır.

- Sakin, destekleyici ve güvenli bir şekilde bakım sağlanır.

- Sevilen müziklerin dinlenilmesi önerilir. Bunun için hasta yakınlarının radyo temin etmesi sağlanır.

- Yeterli dinlenme ve hayal kurma, progresif gevşeme egzersizleri gibi yöntemlerin kullanılması için destek sağlanır. 
Tablo 2. Hemşirelik girişimleri devamı

Benlik kavramında - Değișen beden imajı konusunda değerlendirme yapılır (ikterik görünüm, bozulmuş kas-iskelet yapısı, salya akması vb). rahatsızlık

- Beden imajını bozan asıl nedenin hasta için anlamı, baş etme mekanizmaları, sosyal destek sistemleri değerlendirilir.

- Yas ve öfke duygularının normalleştirilmesi ve ifade edilmesi için teşvik sağlanır.

- Güvenli ve destekleyici bir iletişim kurulur. Aileye beden imajı bozulması durumunda yaklaşımın çok önemli olduğu konusunda bilgi verilir.

- Daha önce benzer deneyimi yaşamış bireylerle iletişim kurularak hastanın rahatlaması sağlanır ve destek gruplara ya da grup terapilerine katılım için cesaretlendirilir.

\begin{tabular}{|c|c|}
\hline $\begin{array}{l}\text { Rolleri yerine } \\
\text { getirmede } \\
\text { yetersizlik }\end{array}$ & $\begin{array}{ll}\text { - } & \text { Iş ve aile ortamındaki rol ve sorumluluklar incelenir. } \\
\text { - } & \text { Destek sistemleri değerlendirilir (aile, arkadaşlar). } \\
\text { - } & \text { Iş ile ilgili güçlüklerin ve son zamanlarda karşılaşılan stresörlerin paylaşılması için cesaretlendirme yapılır. } \\
\text { - } & \text { Duyguların yazılarak ifade edilmesi konusunda fırsat verilir. }\end{array}$ \\
\hline Kanama riski & $\begin{array}{l}\text { - } \quad \text { Şiddetli burun sümkürme, öksürme veya hapşırma gibi zorlayıcı aktivitelerden kaçınılması öğretilir. } \\
\text { - Hasta ve aile bireyleri kanama belirtileri hakkında eğitilir. } \\
\text { - } \quad \text { Hastanın odasında kanama/travmaya neden olabilecek cisimler araştırıır ve gerekli önlemler alınır. } \\
\text { - } \quad \text { Yatak kenarlıkları kaldırıı ve yatak yüksekliği minimum düzeyde tutulur. } \\
\text { - } \quad \text { Çağırma sistemi hasta ve ailesine anlatıı } \\
\end{array}$ \\
\hline $\begin{array}{l}\text { Deri bütünlüğg̈nde } \\
\text { bozulma riski }\end{array}$ & $\begin{array}{l}\text { - Deri bütünlüğü günlük olarak gözlemlenir. } \\
\text { - } \quad \text { Deri her gün enfeksiyon belirtileri açısından değerlendirilir (kızarıkık, ödem, ateş). } \\
\text { - } \quad \text { iki saat aralarla aila pozisyon değişimi sağlanarak hareketlilik kademeli olarak arttırıır. } \\
\text { - } \quad \text { Yatak çarşaflarının gergin olmasına önem verilir. } \\
\text { - } \quad \text { Hastanın yeterli hidrasyonu sıvı alımı ve beslenmesi sağlanır. } \\
\text { - } \quad \text { Bakım veren kişiye hastanın desteklenmesinin önemi vurgulanır. }\end{array}$ \\
\hline Enfeksiyon riski & 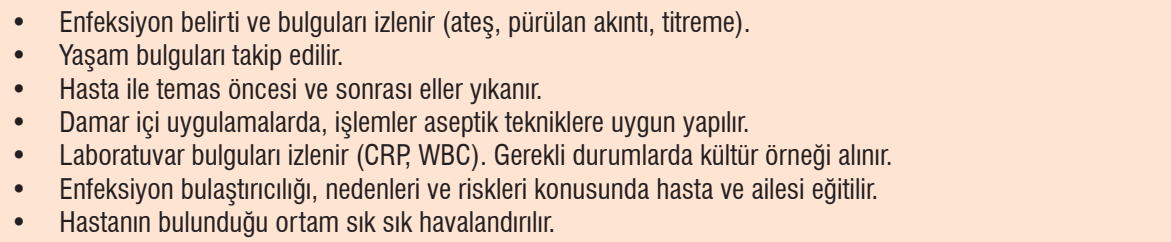 \\
\hline
\end{tabular}

\section{Kaynaklar}

1. Fukui $\mathrm{H}$, Saito H, Ueno $\mathrm{Y}$, Uto H, Obara K, Sakaida I, et al. EvidenceBased Clinical Practice Guidelines for Liver Cirrhosis 2015. J Gastroenterol 2016;51:629-50. [CrossRef]

2. Alt $Y$, Grimm A, Schlegel L, Grambihler A, Kittner JM., Wiltink J, et al. The Impact of Liver Cell Injury on Health Related Quality of Life in Patients with Chronic Liver Disease. PLoS One 2016;18:2-12. [CrossRef]

3. Goel A, Jat SL, Sasi A, Paliwal VK, Aggarwal R. Prevalence, Severity, Andimpact on Quality of Life of Restless Leg Syndrome in Patients with Liver Cirrhosis in India. Indian J Gastroenterol 2016;35:216-21. [CrossRef]

4. Starr SP, Raınes D. Cirrhosis: Diagnosis, Management, and Prevention. American Family Physician 2011; 84:1353-9.

5. Tsochatzis EA, Bosch J, Burroughs AK. Liver Cirrhosis. Lancet. 2014;17;383:1749-61. [CrossRef]

6. Aluçlu MU. İlk Bulgusu Ekstrapiramidal Semptom olan Wilson Hastalığı: Olgu Sunumu. Dicle Tıp Dergisi 2007; 34:127-30.

7. Roberts EA, Schilsky ML. Diagnosis and Treatment of Wilson Disease: An Update. Hepatology 2008;47:2089-111. [CrossRef]

8. Akın A, Keşkek ŞÖ, Aliustaoğlu M, Şahinoğlu-Keşkek N. Maligniteyi Taklit Eden Wilson Hastalığı Olgusu. A Case of Wilson's Disease Mimicking Malignancy. The Medical Bulletin of Haseki Training and Research Hospital 2013:64-6. [CrossRef]

9. Ferenci P. Review Article: Diagnosis and Current Therapy of Wilson's Disease. Aliment Pharmacol Ther 2004;19:157-65.
10. Petmezci MT, Kıhtır HS, Yeşilbaş O, Yüksel E, Balkaya S, Önal Z ve ark. Sitrat Toksisitesi ile Komplike Fulminan Wilson Hastalığı Olgusu. A Case of Fulminant Wilson's Disease Complicated with Citrate Toxicity. Yoğun Bakım Derg 2016:1-3.

11. Haraguchi M, Miyaaki $H$, Ichikawa $T$, Shibata $H$, Honda $T$, Ozawa $E$ et al. Glucose Fluctuations Reduce Quality of Sleepand of Life in Patients with Liver Cirrhosis. Hepatol 2017:125-31. [CrossRef]

12. Rossi D, Galant LH, Marroni CA. Reliability of the Fatigue Severity Scale in Cirrhotic and Correlation with Depression and Quality of LIfe: Preliminary Assessment. Arq Gastroenterol 2016;53:203-5. [CrossRef]

13. Büyükkaya D, Fesci H. Karaciğer Sirozu ve Hemşirelik. Atatürk Üniv. Hemşirelik Yüksekokulu Dergisi 2006;9:111-17.

14. Özkaraman A, Özer S, Balcı Alpaslan G. Romatoid Artritli Bir Vakanın Hemşirelik Bakımında Roy Adaptasyon Modelinin Kullanımı. Gümüşhane Üniversitesi Sağlık Bilimleri Dergisi 2012;1:138-52.

15. Özgürsoy Uran BN, Özer S, Yıldırım Y. Watson İnsan Bakım Modeli Uygulamasına Bir Örnek: Kalp Yetersizliği Olgusu. an Example of Watson's Theory of Human Caring Model: Case of Heart Failure. Türk Kardiyol Dern Kardiyovasküler Hemşirelik Dergisi 2015;6:183-98. [CrossRef]

16. Özer S, Gökçe S. Neuman Sistemler Modelinin Hemodiyaliz Tedavisi Gören Bir Olguda Uygulanması. Applying the Neuman Systems Model in a Hemodialysis Treatment Case. HEAD. 2015;12:69-77. [CrossRef]

17. Alligood MR. Nursing Theory Utilization \& Application. 5nd edition. Karen Moore Schaefer Levine's Conservation Model in Nursing Practice, 2014, pp.181-5. 
18. Levine, ME. On Creativity in Nursing. Image 1973; 5:15-9. [CrossRef]

19. Abumaria IM, Hastings-Tolsma M, Sakraida TJ. Levine's Conservation Model: A Framework for Advanced Gerontology Nursing Practice. Nurs Forum 2015;50:179-88. [CrossRef]

20. Levine ME. On the Humanities in Nursing. Canadian Journal of Nursing Research 1999; 30; 213-7.

21. Leach MJ. Wound Management: Using Levine's Conservation Model to Guide Practice. Ostomy Wound Manage. 2006 ;52:74-80.
22. Mefford LC, Alligood MR. Evaluating Nurse Staffing Patterns and Neonatal Intensive Care Unit out Comes Using Levine's Conservation Model of Nursing. J Nurs Manag 2011;19:998-1011. [CrossRef]

23. Carpenito-Moyet LJ. Diagnostic Clusters, Neurological Disorders. In: Carpenito- Moyet LJ, ed. Erdemir F, Hemşirelik Tanıları El Kitabı. 13.Baskı. İstanbul: Nobel Tıp Kitabevleri. 2012, pp.667-9.

24. Kavurmacı M, Tan M. Üremik Kaşıntı ve Hemşirelik Bakımı. Anadolu Hemşirelik ve Sağlık Bilimleri Dergisi 2015;18:57-62. 